\title{
Long-term changes in precipitation and stream water chemistry in small forest and moorland catchments at Beddgelert Forest, north Wales
}

\author{
B. Reynolds ${ }^{1}$, P.A. Stevens ${ }^{1}$, S.A. Brittain ${ }^{1}$, D.A. Norris ${ }^{1}$, S. Hughes ${ }^{1}$ and C. Woods ${ }^{2}$ \\ ${ }^{1}$ Centre for Ecology and Hydrology Bangor, Orton Building, Deiniol Road, Bangor Gwynedd, LL57 2UP, Wales, UK \\ ${ }^{2}$ Centre for Ecology and Hydrology, Lancaster Environment Centre, Library Avenue, Bailrig, Lancaster, LA1 4AP, UK
}

Email for corresponding author: br@ceh.ac.uk

\begin{abstract}
Changes in the chemistry of bulk precipitation and stream water between 1982 and 2000 are described for small moorland and forest catchments located within Beddgelert Forest in north Wales. Two forest catchments were partially clearfelled in 1984 (D2; 68\% and D4; 28\%) whilst a third (D3) remained as an unfelled control until autumn / winter 1998/99 when partial felling took place in the headwaters. Over the monitoring period, the annual mean $\mathrm{pH}$ of bulk precipitation increased from 4.6 to 5.1 whilst the annual mean non-seasalt sulphate concentration decreased from $0.53 \mathrm{mg} \mathrm{S}^{-1}$ in 1985 to $0.24 \mathrm{mg} \mathrm{S}^{-1}$ in 2000 . Since 1985 , the annual wet deposition flux of non-seasalt sulphur decreased by $50 \%$ to $8.4 \mathrm{~kg} \mathrm{~S} \mathrm{ha}^{-1} \mathrm{yr}^{-1}$ in 2000. Annual mean inorganic nitrogen concentrations and annual wet deposition fluxes have remained relatively unchanged since 1982. The decrease in atmospheric sulphur deposition is reflected by decreased annual mean concentrations of non-seasalt sulphur, acidity, aluminium and calcium in all four streams irrespective of clearfelling activities. Annual variations in nitrate-N and potassium concentrations in the forest streams, largely determined by pulses of leaching following forest clearance, had no effect on stream acidity. In common with UK upland catchments, annual mean concentrations of dissolved organic carbon have increased from about $1 \mathrm{mg} \mathrm{C1^{-1 }}$ in 1985 to between 1.5 and $2 \mathrm{mg} \mathrm{C}^{-1}$ in 2000 , although there is considerable year to year variability. Two boreholes drilled adjacent to catchments D3 and D4 have confirmed the presence of alkaline, base rich groundwater at Beddgelert. Although the boreholes are only $150 \mathrm{~m}$ apart, there are large differences in chemistry suggesting that different groundwater reservoirs have been intercepted providing further evidence of the complexity and heterogeneity of groundwater systems in upland catchments.
\end{abstract}

Keywords: acid deposition, acidification, recovery, forestry, clearfelling, trends, Beddgelert, streams, rainfall

\section{Introduction}

The Beddgelert forest clearfelling study began in 1982 in response to concerns about the potential environmental effects of widespread harvesting of mature conifer plantations in the UK uplands (Blackie et al., 1980). These concerns focused around issues of soil nutrient depletion and acidification associated with biomass removal and leaching losses at harvest, plus the debate over the respective roles of acid deposition and forestry in surface water acidification (Harriman and Morrison, 1982; Stoner et al., 1984). Whilst relevant information was available from studies in North America (e.g. Likens et al., 1977; Bormann and Likens, 1979; Feller, 1977), the combination of site type and forest management practice found in the UK was not represented. Many north American studies focused either on clearcutting of primary forest containing trees of mixed ages or on plantations established on clearcut primary forest in which case felling debris was often subject to controlled burning (Brown and Krygier, 1971). In contrast, UK forest practice in the early 1980s involved clear-felling entire stands of even-aged conifers, mainly Sitka spruce (Picea sitchensis (Bong.) Carr.), leaving perhaps a few trees or groups of trees for amenity purposes. Conventional harvesting techniques removed the stem only, leaving felling debris consisting of needles, branches and stems $(<7 \mathrm{~cm}$ diameter) on site. This debris provided a potential source of 
nutrients for the succeeding crop, which was generally planted within two years.

The CEH Bangor study in Beddgelert forest was originally conceived as a replicated, block design, plot experiment comparing the biogeochemical effects of conventional harvesting with those of whole tree harvesting in which all the above ground biomass was removed. However, the location of the experiment provided an opportunity to monitor water quality responses to felling in three first order streams within the forest. A fourth stream adjacent to the forest, draining semi-natural moorland, was also sampled. As the catchments were located in an acid sensitive area (Hornung et al., 1995) receiving large inputs of acid deposition (Reynolds et al., 1999), the sites provide valuable information on the hydrochemical response to changing acid inputs over the last 20 years.

Much of the published work from Beddgelert has focused on the short to medium term dynamics of the major nutrients in response to harvesting, that is of the order of one to three years (e.g. Fahey et al., 1991a,b; Stevens et al., 1989, 1993, 1995). Particular focus was placed on nitrogen concentrations and fluxes (Stevens and Hornung, 1988, 1990; Stevens et al., 1993) including some detailed process studies of the controls on nitrate leaching following harvesting (Emmett and Quarmby, 1991; Emmett et al., 1991a,b). A broader consideration of the water quality impacts of felling in Beddgelert forest (covering a monitoring period of about seven years) was presented by Reynolds et al. (1995). The hydrochemistry of sites in Beddgelert forest was also described as part of a broader investigation into the interactions between atmospheric nitrogen deposition and tree age (Stevens et al., 1993, 1995; Hughes et al., 1994).

Although the soil plot studies have been discontinued for many years, monitoring of bulk precipitation and stream water chemistry has continued. This paper summarises these data to provide a long-term perspective on the earlier, more intensive studies and to show how the streams have responded over a twenty year period to changes in forest management (clearfelling) and acid deposition inputs.

\section{Sites and methods}

Beddgelert forest is located in the mountains of Snowdonia in north Wales. The forest study catchments D2 (1.4 ha), D3 (4.7 ha) and D4 (6.1 ha) are located in a north-east facing former glacial cwm known as $\mathrm{Cwm} \mathrm{Du}$ and the moorland site (D6) is in the adjacent Cwm Marchnad. The altitude range of the catchments is between 250 and $700 \mathrm{~m}$ with an average annual rainfall of $c .2800 \mathrm{~mm}(1982-2000$ at $330 \mathrm{~m}$ altitude).
The geology of the two cwms is primarily Ordovician slates with small intrusions of dolerite and an area of microgranite at the top of Cwm Marchnad. Glacial and slope deposits comprising locally derived clay-rich tills and compacted sandy gravels occur widely in Cwm Du whilst soils comprise a variety of acid upland types, dominated by stagnopodzols. The main area of forest in Cwm Du was established between 1931 and 1936 on agriculturally unimproved semi-natural grassland and heath. The trees were planted without ploughing as a 50:50 mixture of Sitka and Norway spruce, but subsequent thinning reduced the proportion of Norway spruce to $10 \%$. In $1984,62 \%$ of D2 and $28 \%$ of D4 were clearfelled, whilst D3 remained as an unfelled control site with closed canopy forest and no ground flora apart from scattered ferns and bryophytes. The top parts of D3 and D4 were clearfelled in the autumn and winter of 1998/99. The non-forested Cwm Marchnad comprises acid grassland dominated by Nardus, Festuca and Molinia and is grazed at low intensity by sheep.

\section{SAMPLE COLLECTION}

Water quality monitoring has been undertaken for rainfall, stream runoff and groundwater. The sampling programme was as follows. Rainfall was collected using a continuously open collector located in a clearing in Cwm Du. Samples were collected every two weeks from January 1982 until January 1992 when monthly sampling was introduced. Samples of stream water were collected weekly from D2, D3 and D4 from January 1982 until January 1992 when monthly sampling was introduced. Weekly sampling at D6 commenced in March 1983 and continued until the introduction of monthly sampling in January 1992. The data presented in this paper run to January 2001.

During the summer of 1994 two boreholes were drilled in Cwm Du immediately downslope of catchments D4 (hole BG1) and D3 (hole BG2). Initially, the boreholes were sampled every week between September 1994 and January 1995 and subsequently fortnightly until December 2000.

Within the study, hydrological measurements have also been taken. In the case of rainfall, the amount of rain falling during the sampling period was recorded from the bulk deposition collectors. A limited and incomplete record of water level at the time of sampling is available from small V-notch weirs installed in streams D3 and D4. These ceased operation in April 1989 for D4 and March 2000 for D3. For groundwater, the height of the water table was measured manually on each sampling occasion.

\section{CHEMICAL ANALYSES}

On return to the laboratory in Bangor, $\mathrm{pH}$ was determined 
electrometrically on an unfiltered subsample. The remainder of the sample was filtered through a $0.45 \mu \mathrm{m}$ membrane filter prior to analysis for major cations, anions, dissolved organic carbon (DOC) and silicon.

From October 1994 onwards, alkalinity has also been determined on the unfiltered sample by Gran titration. Since 1982, sodium and potassium have been determined by flame emission spectrometry while calcium, magnesium and manganese have been determined by flame atomic absorption spectrometry using a Perkin Elmer model 280 instrument. Up to September 1984, nitrate, chloride and ammonium were determined by continuous flow colorimetry after which ion chromatography was used. The methods were extensively cross-checked to ensure that no bias was introduced into the data. Sulphate was determined by a barium chloride turbidimetric method until the introduction of ion chromatography in September 1984. The barium chloride method was very insensitive at the concentration range encountered in the samples, so that data prior to September 1984 have been discarded. Since 1982, silicon has been determined by continuous flow colorimetry using the molybdenum blue method. DOC was determined from 1984 onwards using continuous flow colorimetry in which the samples were acidified and purged of $\mathrm{CO}_{2}$ with nitrogen followed by UV digestion with potassium persulphate and determination of evolved $\mathrm{CO}_{2}$ using weakly buffered phenolphthalein. Total monomeric aluminium has been determined since 1990 using the method proposed by Seip et al. (1984) followed by colorimetric analysis using pyrocatechol violet (Dougan and Wilson, 1974).

\section{Results}

\section{BULK PRECIPITATION CHEMISTRY}

\section{Summary}

The chemical composition of bulk precipitation at Beddgelert is summarised as annual rainfall-volume weighted means and ranges for the period 1982-2000 inclusive in Table 1. The excess or non-seasalt components have been calculated using theoretical seasalt ratios, assuming all sodium originated as seasalt. Bulk precipitation is typically dilute, (mean conductivity $22 \mu \mathrm{S} \mathrm{cm}^{-1}$ ) and acidic (mean $\mathrm{pH}$ 4.76). The overall mean sodium to chloride ratio $(0.56)$ is very close to the theoretical value for seawater of 0.55 and seasalts account for $78 \%$ of the total ion sum. Approximately $66 \%$ of the sulphur in precipitation originates from non-seasalt sources and of this about $10 \%$ is contributed by the oxidation of marine biogenic dimethylsulphide (McArdle et al., 1998).
Table 1. Rainfall volume weighted mean, minimum and maximum solute concentrations in bulk precipitation collected at Beddgelert forest between 1982 and 2000 inclusive.

\begin{tabular}{|c|c|c|c|}
\hline & Mean & Min & $\operatorname{Max}$ \\
\hline $\mathrm{pH}$ & 4.76 & 3.48 & 6.92 \\
\hline $\mathrm{Na}\left(\mathrm{mg} \mathrm{l}^{-1}\right)$ & 2.5 & $<0.1$ & 12.2 \\
\hline $\mathrm{K}\left(\mathrm{mg} \mathrm{l}^{-1}\right)$ & 0.11 & $<0.01$ & 0.85 \\
\hline $\mathrm{Ca}\left(\mathrm{mg} \mathrm{l}^{-1}\right)$ & 0.24 & 0.02 & 6.00 \\
\hline $\operatorname{Mg}\left(\mathrm{mg} \mathrm{l}^{-1}\right)$ & 0.31 & $<0.01$ & 2.16 \\
\hline $\mathrm{NH}_{4}-\mathrm{N}\left(\mathrm{mg} \mathrm{l}^{-1}\right)$ & 0.22 & $<0.01$ & 3.46 \\
\hline $\mathrm{NO}_{3}-\mathrm{N}\left(\mathrm{mg} \mathrm{l}^{-1}\right)$ & 0.18 & $<0.01$ & 2.30 \\
\hline${ }^{1} \mathrm{SO}_{4}-\mathrm{S}\left(\mathrm{mg} \mathrm{l}^{-1}\right)$ & 0.59 & 0.15 & 4.50 \\
\hline${ }^{1} \mathrm{nmSO}_{4}-\mathrm{S}\left(\mathrm{mg} \mathrm{l}^{-1}\right)$ & 0.39 & $<0.01$ & 4.11 \\
\hline $\mathrm{Cl}\left(\mathrm{mg} \mathrm{l}^{-1}\right)$ & 4.39 & 0.25 & 21.00 \\
\hline${ }^{1} \mathrm{DOC}\left(\mathrm{mg} \mathrm{l}^{-1}\right)$ & 0.57 & 0.05 & 7.50 \\
\hline
\end{tabular}

${ }^{1}$ Data from 1985 to 2000 inclusive.

\section{Changes in concentration and flux over time}

Downward trends in excess sulphate concentration and acidity were reported for Beddgelert by Reynolds et al. (1999). Subsequently, these trends have been sustained (Fig. 1) such that the annual rainfall weighted mean non-seasalt sulphate-S concentration has more than halved from 0.53 $\mathrm{mg} \mathrm{S} 1^{-1}$ in 1985 to $0.24 \mathrm{mg} \mathrm{S} \mathrm{l}^{-1}$ in 2000 . Over the same period, $\mathrm{pH}$ has increased from 4.6 to 5.1, making the decrease in annual mean sulphate and hydrogen ion concentrations approximately equal ( 17 to $18 \mu \mathrm{Eq} \mathrm{l}^{-1}$ ). The annual mean equivalent ratio of excess sulphate to nitrate has also decreased from 2.2 in 1985 to 1.5 in 2000. Sulphate remains the dominant acid anion in bulk precipitation, but its importance relative to nitrate has declined. Annual mean concentrations of seasalt ions have varied in a broad cyclical pattern with maxima in the mid-1980s, 1990 and 1997 (Fig. 1). Excess calcium concentrations also show similar cyclical variations, with minima in 1986, 1991 and 1996.

Annual fluxes have been estimated for the site using precipitation volumes measured in the rain chemistry collector. Whilst these volumes may not be 'accurate' in absolute terms, since the collectors are not at ground level, they should provide a reliable indicator of inter-annual variability in rainfall totals.

There has been a clear decline in non-seasalt sulphur deposition since 1985 (Fig. 2). In 2000, sulphur deposition $\left(8.4 \mathrm{~kg} \mathrm{~S} \mathrm{ha}^{-1} \mathrm{yr}^{-1}\right)$ was approximately half that in 1985 (17.1 $\left.\mathrm{kg} \mathrm{S} \mathrm{ha}^{-1} \mathrm{yr}^{-1}\right)$. The decline has not been linear and large fluctuations have occurred over the 16 year period with the lowest deposition fluxes recorded in $1995\left(6.9 \mathrm{~kg} \mathrm{~S} \mathrm{ha}^{-1} \mathrm{yr}^{-1}\right)$ and $1999\left(6.5 \mathrm{kgS} \mathrm{ha}^{-1} \mathrm{yr}^{-1}\right)$. These fluctuations cannot be 

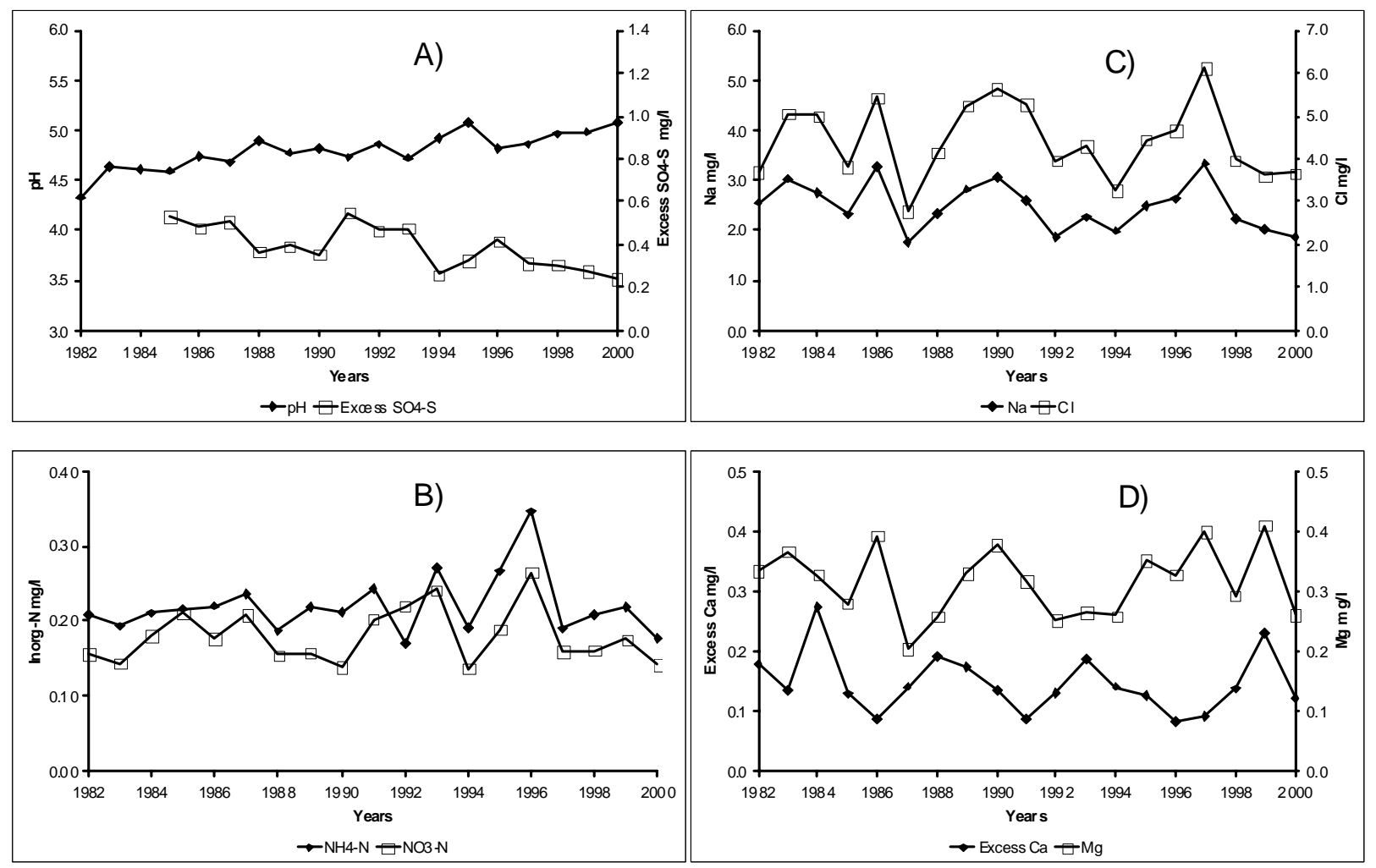

Fig. 1. Time series plots of (A) annual mean pH and annual mean non-seasalt sulphate-S concentrations; (B) annual mean inorganic nitrogen concentrations; (C) annual mean sodium and chloride concentrations; (D) annual mean non-seasalt calcium and magnesium concentrations in bulk precipitation at Beddgelert Forest.
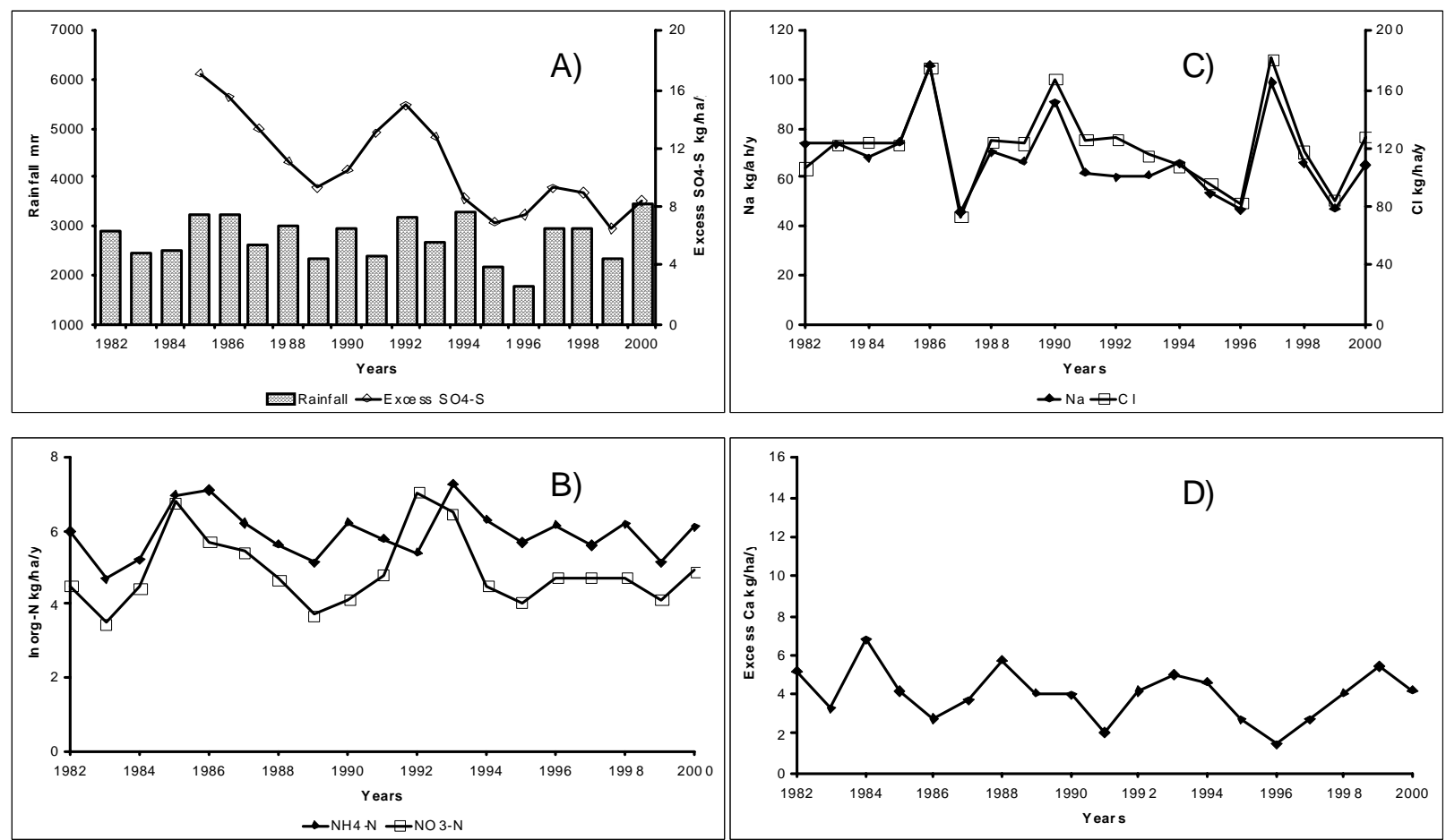

Fig. 2. Time series plots of (A) annual rainfall and non-seasalt sulphate-S deposition; (B) annual inorganic nitrogen deposition; (C) annual sodium and chloride deposition; (D) annual non-seasalt calcium deposition at Beddgelert forest. 
attributed solely to variability in annual rainfall amounts, although these influence year to year differences in deposition. Annual deposition of inorganic nitrogen and seasalts show no clear trends although again there are large year to year fluctuations, which are not directly correlated with rainfall amount (Fig. 2). A weak downward trend in non-seasalt calcium deposition is discernible, but with large inter-annual variations in annual fluxes.

\section{STREAM WATERS}

\section{Summary}

The long-term average chemical composition of the three forest streams (D2, D3 and D4) is very similar (Table 2) despite the changes in forest cover as a result of clearfelling. All three streams are very acid with negative alkalinities. In comparison to D6, the forest streams are more acid, more aluminium rich and contain much higher concentrations of seasalts and nitrate. For some solutes (acidity, aluminium, base cations, silicon and sulphate; Figs. 3 to 5), these broad differences have been maintained throughout much of the monitoring period. These differences probably reflect subtle differences in bedrock geology between the forest catchments and D6 and the continuing presence of significant areas of mature forest canopy. For the nutrients, a more complex pattern reflects transient pulses of nitrate and potassium in response to felling and longer-term changes in nutrient release as the new forest develops. Nitrate is the main form of inorganic nitrogen in the streams and mean concentrations of ammonium are close to the detection limit. The consistently high streamwater nitrate concentrations in the unfelled forest catchment (D3) prior to felling activity in 1998/9 have been attributed to the effects of stand age combined with large atmospheric inputs of inorganic

Table 2. Arithmetic mean, minimum and maximum in solute concentrations in streams draining forest and moorland catchments at Beddgelert forest.

\begin{tabular}{|c|c|c|c|c|}
\hline & D2 & D3 & $D 4$ & D6 \\
\hline \multirow[t]{2}{*}{$\mathrm{pH}$} & 4.62 & 4.66 & 4.63 & 4.92 \\
\hline & $3.95-5.61$ & $4.04-5.36$ & $4.05-5.44$ & $4.36-5.55$ \\
\hline \multirow[t]{2}{*}{$\operatorname{Alk}\left(\mu \mathrm{Eq} \mathrm{l^{-1 }}\right)$} & -13.0 & -18.5 & -19.0 & -10.8 \\
\hline & $-62.3-+8.0$ & $-63.4-+1.7$ & $-77.7-+5.1$ & $-43.3-+3.4$ \\
\hline \multirow[t]{2}{*}{$\mathrm{Na}\left(\mathrm{mg} \mathrm{l}^{-1}\right)$} & 6.3 & 6.7 & 5.5 & 3.7 \\
\hline & $3.1-12.4$ & $3.1-16.5$ & $2.4-12.3$ & $2.2-7.5$ \\
\hline \multirow[t]{2}{*}{$\mathrm{K}\left(\mathrm{mg} \mathrm{l}^{-1}\right)$} & 0.25 & 0.23 & 0.19 & 0.10 \\
\hline & $0.01-1.28$ & $0.01-3.59$ & $0.01-1.76$ & $0.01-1.22$ \\
\hline \multirow[t]{2}{*}{$\mathrm{Ca}\left(\mathrm{mg} \mathrm{l}^{-1}\right)$} & 1.02 & 1.94 & 1.33 & 0.78 \\
\hline & $0.34-3.12$ & $0.21-4.10$ & $0.13-3.90$ & $0.42-1.60$ \\
\hline \multirow[t]{2}{*}{$\operatorname{Mg}\left(\mathrm{mg} \mathrm{l}^{-1}\right)$} & 0.84 & 0.97 & 0.81 & 0.54 \\
\hline & $0.17-1.60$ & $0.52-1.76$ & $0.14-1.9$ & $0.03-1.74$ \\
\hline \multirow[t]{2}{*}{$\operatorname{Mn}\left(\mathrm{mg} \mathrm{l}^{-1}\right)$} & 0.16 & 0.21 & 0.17 & 0.05 \\
\hline & $0.02-0.98$ & $0.02-1.87$ & $0.01-0.92$ & $0.01-3.00$ \\
\hline \multirow[t]{2}{*}{$\mathrm{Al}\left(\mathrm{mg} \mathrm{l}^{-1}\right)$} & 0.43 & 0.50 & 0.53 & 0.11 \\
\hline & $0.04-1.20$ & $0.07-1.16$ & $0.04-1.32$ & $0.01-0.60$ \\
\hline \multirow[t]{2}{*}{$\mathrm{NH}_{4}-\mathrm{N}\left(\mathrm{mg} \mathrm{l}^{-1}\right)$} & 0.05 & 0.05 & 0.05 & 0.05 \\
\hline & $<0.01-0.30$ & $<0.01-0.68$ & $<0.01-0.37$ & $<0.01-0.68$ \\
\hline \multirow{2}{*}{$\mathrm{NO}_{3}-\mathrm{N}\left(\mathrm{mg} \mathrm{l}^{-1}\right)$} & 0.52 & 0.78 & 0.75 & 0.12 \\
\hline & $0.01-2.00$ & $0.18-3.55$ & $0.12-3.46$ & $0.01-1.20$ \\
\hline \multirow[t]{2}{*}{$\mathrm{SO}_{4}-\mathrm{S}\left(\mathrm{mg} \mathrm{l}^{-1}\right)$} & 1.89 & 2.27 & 1.91 & 1.17 \\
\hline & $0.43-5.7$ & $1.16-4.10$ & $0.86-4.20$ & $0.48-3.00$ \\
\hline \multirow[t]{2}{*}{$\mathrm{Cl}\left(\mathrm{mg} \mathrm{l}^{-1}\right)$} & 11.6 & 12.3 & 10.3 & 6.6 \\
\hline & $4.0-29.0$ & $3.9-36.0$ & $3.4-23.0$ & $1.2-15.0$ \\
\hline \multirow[t]{2}{*}{$\mathrm{Si}\left(\mathrm{mg} \mathrm{l}^{-1}\right)$} & 0.92 & 1.01 & 0.94 & 0.56 \\
\hline & $0.09-1.40$ & $0.29-1.52$ & $0.26-2.00$ & $0.10-1.10$ \\
\hline \multirow[t]{2}{*}{ DOC $\left(\mathrm{mg} \mathrm{l}^{-1}\right)$} & 1.42 & 1.21 & 1.03 & 1.01 \\
\hline & $0.08-18.0$ & $0.08-9.30$ & $0.08-11.00$ & $0.08-6.30$ \\
\hline \multirow[t]{2}{*}{ Cond $\left(\mu \mathrm{S} \mathrm{cm}{ }^{-1}\right)$} & 56 & 70 & 62 & 36 \\
\hline & $29-91$ & $38-103$ & $39-124$ & $21-54$ \\
\hline
\end{tabular}


nitrogen (Stevens et al., 1993, 1995; Emmett et al., 1995). This catchment has been described as 'nitrogen saturated' (Stevens et al., 1990), with seasonal maxima in stream water nitrate concentrations in summer; this is typical of 'nitrogen saturated' catchments (Stoddard, 1994) and the reverse of the more common pattern observed in the moorland catchment (Stevens et al., 1993).

\section{Changes in concentration over time}

Different water quality determinands have shown several types of trend over time across the four catchments. The salient features are as follows.

- Sulphur, acidity and aluminium (Fig. 3). All four streams show a steady decline in annual mean sulphateS concentrations since 1985 which broadly reflect the overall $50 \%$ decrease in excess sulphate-S deposition. The trends in the streams can be approximated by simple linear regression models (all significant at $\mathrm{p}<0.01 ; \mathrm{r}^{2}$ values of between 0.6 and 0.8 ). The greatest rate of change in annual mean sulphate concentration occurred in $\mathrm{D} 2$ corresponding to a decline of $0.82 \mathrm{mg} \mathrm{S} \mathrm{l}^{-1}$ in 16 years; equivalent to halving the annual mean concentration since 1985. A slower rate of change was observed in stream D6 corresponding to a decrease of $0.47 \mathrm{mg} \mathrm{S} \mathrm{I}^{-1}$ equivalent to about $44 \%$ of the 1985 value. The downward trends are evident for excess sulphate$\mathrm{S}$ (calculated assuming all chloride is of seasalt origin), but with more inter-annual variation due to fluctuations in stream water chloride concentrations. Since 1982, the $\mathrm{pH}$ in all streams has increased by about 0.5 units, although the forest streams have been consistently more acid throughout the monitoring period. In the moorland stream, the change in $\mathrm{pH}$ equates to a decrease in hydrogen ion concentration of about $50 \%$ from an

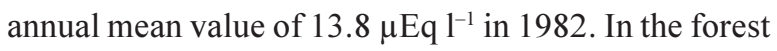
stream D2, for example, the decline in annual mean hydrogen ion concentration has been much larger; a $73 \%$ decrease from a 1982 value of $55 \mu \mathrm{Eq} \mathrm{1}^{-1}$. In the moorland stream (D6), annual mean aluminium concentrations have declined steadily. The annual mean value in $2000\left(0.06 \mathrm{mg} \mathrm{l}^{-1}\right)$ was one third of the 1990 value, whilst the corresponding decrease in the forest streams was about $60 \%$ from a 1990 value of $0.71 \mathrm{mg}$ $1^{-1}$.

- Nitrate and potassium (Fig. 4). For the forest streams the inter-annual variations in mean concentrations of these nutrients reflect the responses to clear felling described previously (Stevens and Hornung, 1988; Reynolds et al., 1995). The most striking changes are seen in stream D2 where annual mean nitrate-N concentrations peaked at $1.2 \mathrm{mg} \mathrm{N}^{-1}$ in 1985 a year after felling, and dropped to values typical of the moorland stream (D6) by 1994. The response to more recent felling can be seen in streams D3 and D4. Superimposed on the felling response is a cyclical pattern of variation seen most clearly in D3 and D6, with concentration maxima in 1985, 1998 and 1996. These correspond to the patterns described for the UK Acid Waters Monitoring Network (AWMN) sites and at Plynlimon (Monteith et al., 2000) which link longterm variations in stream and lake water nitrate concentrations to the North Atlantic Oscillation. This is likely to explain the sharp increase in nitrate concentrations in D2 between 1995 and 1996. No changes in forest management occurred during this period and it is unlikely that a change in forest nutrient cycling is responsible, as concentrations had returned to moorland values by 2000 . For potassium the effects of felling in catchments D2 and D4 are evident from 1985 to 1987, and latterly in D3 and D4 between 1999 and 2000. Prior to 1995, potassium concentrations in both felled catchments (D2 and D4) had declined to values observed in D6. However, there was a sharp increase in potassium in D2 between 1995 and 1996, matching the increase in nitrate-N.

- Seasalts (sodium, magnesium and chloride) and calcium (Fig. 4 and 5). Sodium and chloride have no major sources within the catchment, so that patterns of variation are determined by atmospheric inputs which can in turn be linked to regional climatic influences such as the North Atlantic Oscillation (Evans et al., 2001a). The large annual mean values in 1984 and 1990 reflect the influence of specific deposition events in the spring of those years. Data from daily rainfall collection at primary sites of the UK Acid Deposition Monitoring Network (ADMN) show that chloride deposition is highly episodic and primarily a winter phenomenon (NEGTAP, 2001). However, there is considerable damping of the rainfall chloride signal in surface waters reflecting hydrological mixing and storage processes within the catchment (Neal and Kirchner, 2000) Although magnesium originates from both atmospheric and weathering sources, the former dominates and annual mean concentrations are highly correlated with sodium and chloride. In contrast, weathering is a major source of calcium and its inter-annual variation is determined by periods of low rainfall when stream chemistry is dominated by baseflow. However, in the forest streams, there is a weak downward trend in annual mean calcium concentration, which is not apparent in D6. 

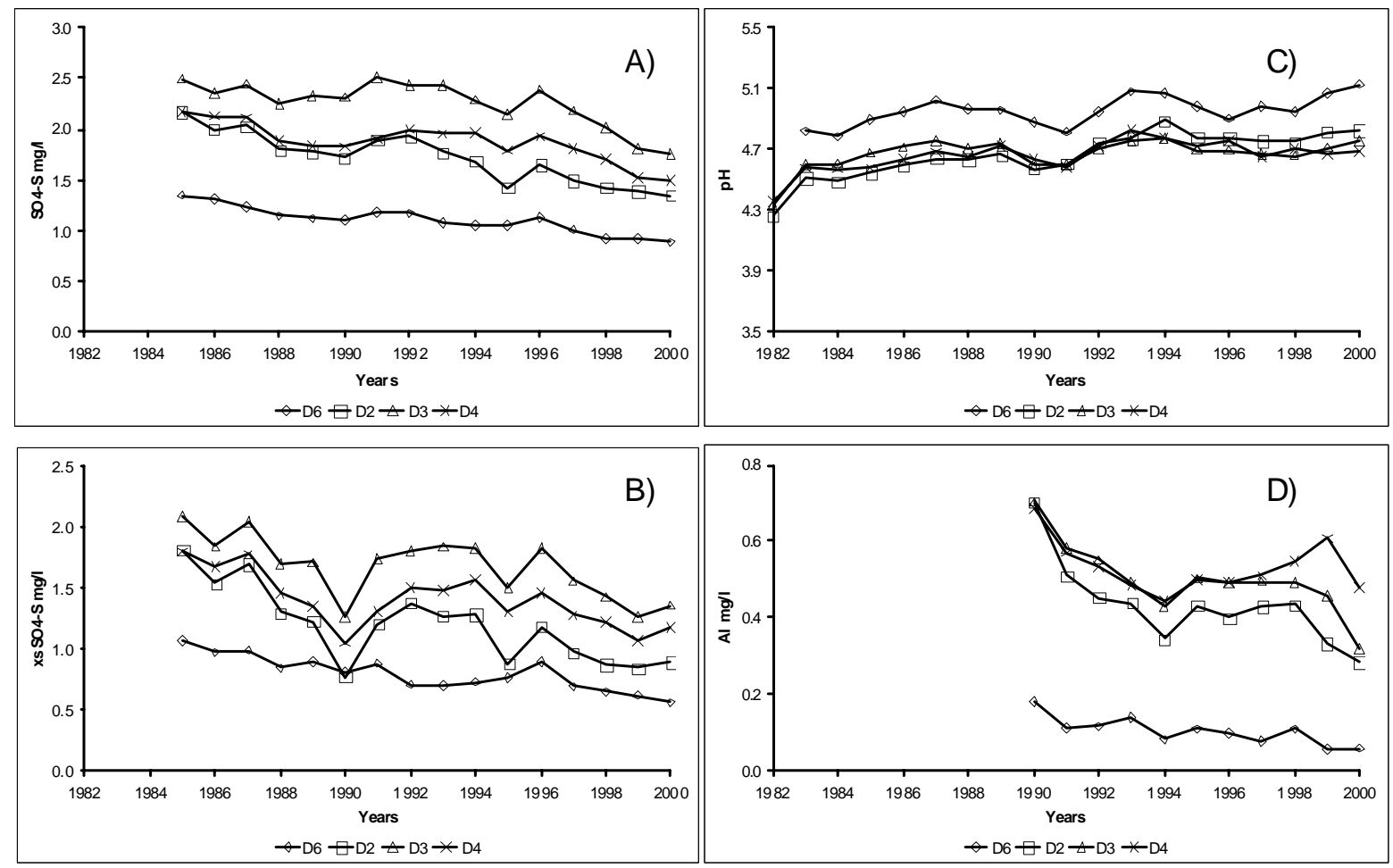

Fig. 3. Time series plots of (A) annual mean sulphate-S concentrations; (B) annual mean non-seasalt sulphate-S concentrations; (C) annual mean $\mathrm{pH}$; (D) annual mean total monomeric aluminium concentrations in four streams at Beddgelert forest.
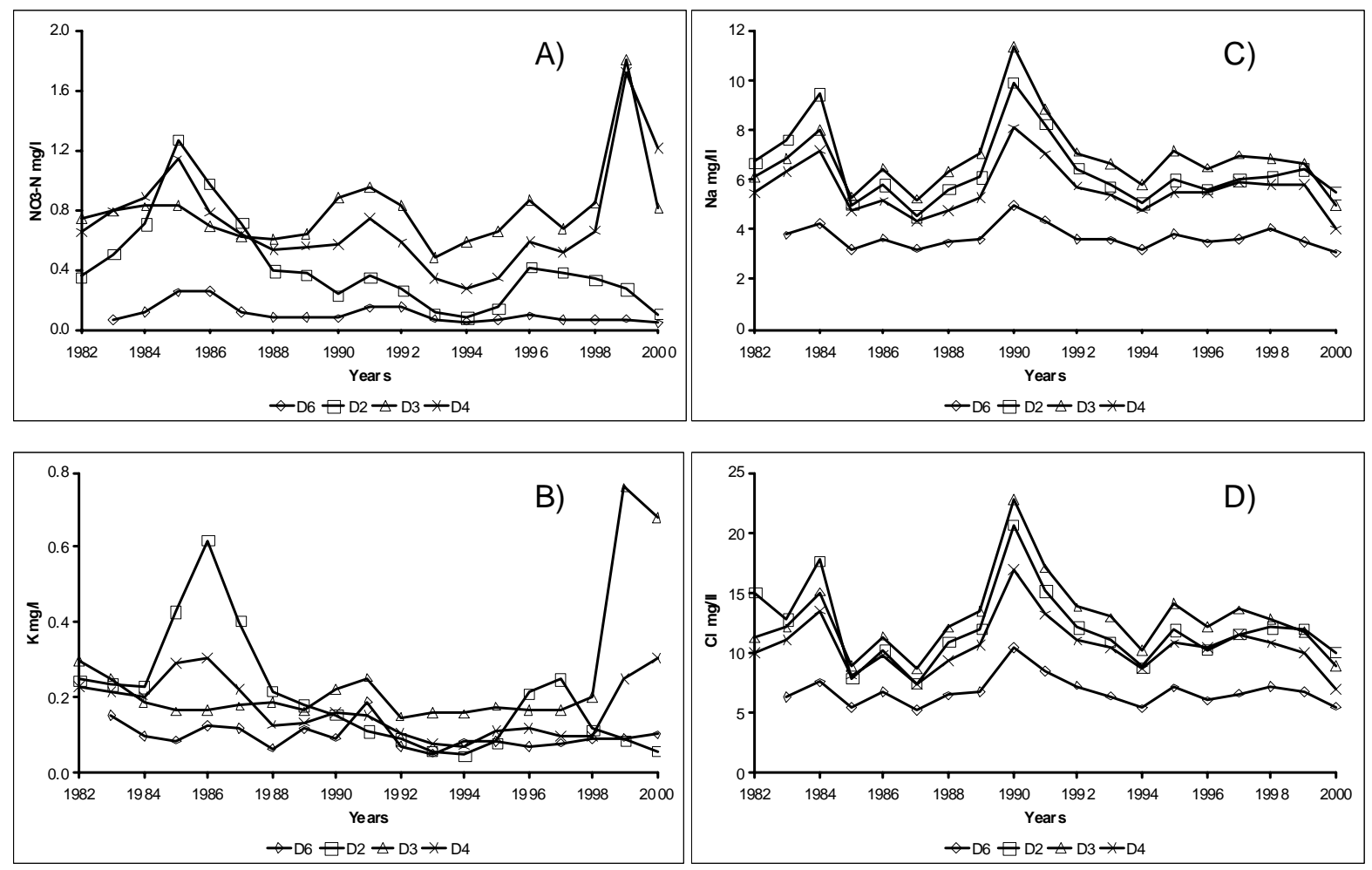

Fig. 4. Time series plots of annual mean concentrations of (A) nitrate-N; (B) potassium; (C) sodium; (D) chloride in four streams at Beddgelert forest. 

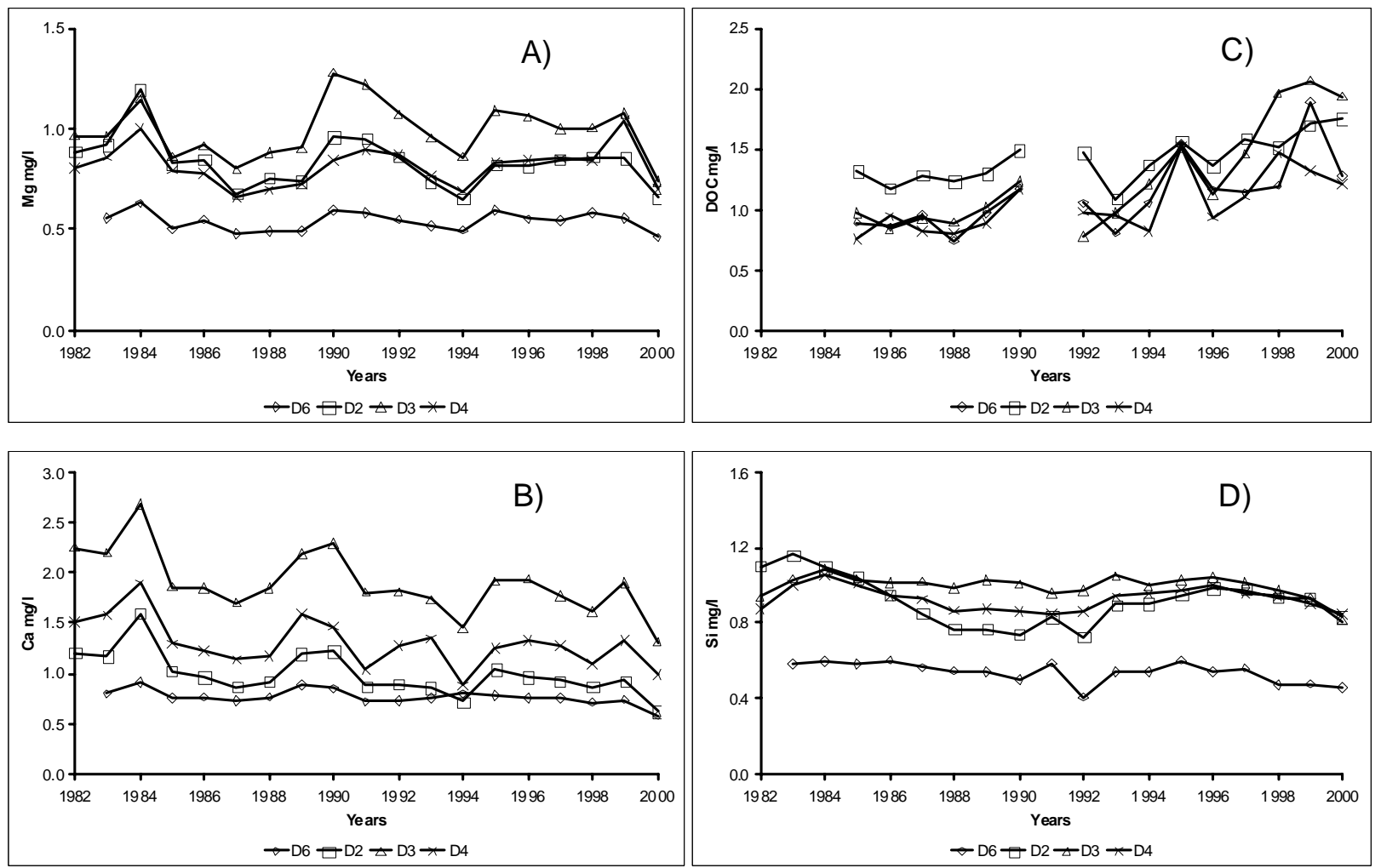

Fig. 5. Time series plots of annual mean concentrations of (A) magnesium; (B) calcium; (C) DOC; (D) silicon in four streams at Beddgelert forest.

DOC and silicon (Fig. 5). In common with many upland streams (Freeman et al., 2001), DOC concentrations have increased in all four streams at Beddgelert, although there is considerable inter-annual variability. Annual mean concentrations of silicon are remarkably constant over time; in the forest streams between 0.9 and $1.1 \mathrm{mg} \mathrm{l}^{-1}$ whilst D6 ranges between 0.4 and 0.6 $\mathrm{mg} \mathrm{l}^{-1}$. Silicon is derived primarily from weathering and variations in bedrock geochemistry may explain the differences between the moorland and forest streams. In all four streams, waters are just undersaturated with respect to quartz (Neal et al., 2004c). The degree of undersaturation increases at high flows when water is derived from organic-rich soil horizons, which are depleted in silicate minerals.

\section{GROUNDWATER}

The chemistry of all four streams follows the classic response to changes in flow, becoming more acidic and aluminiumrich under high flows when soil water inputs dominate and more alkaline, calcium-rich at baseflow (Reynolds, et al., 1986). To explain these fluctuations, a source of base rich water was required within the catchments. This could not be provided from the known chemistry of soil waters, which are acid, aluminium-rich and depleted in calcium throughout the profile (Stevens et al., 1989). Following the discovery of groundwater at Plynlimon (Neal et al., 1997), two boreholes were drilled in Beddgelert forest in 1994; both encountered groundwater.

The chemical data from the boreholes (Table 3) contrast markedly with those from the streams (Table 2). The borehole waters are circumneutral, with high, positive alkalinities. Levels of dissolved carbon dioxide in these waters can be estimated using the approximation developed by Neal et al. (1998) where:

$$
\mathrm{EpCO}_{2} \mathrm{H} \cdot\left(\text { Gran Alkalinity }+10^{6-\mathrm{pH}}\right) * 10^{6-\mathrm{pH}} / 6 \text {. }
$$

$\mathrm{EpCO}_{2}$ is the degree of $\mathrm{CO}_{2}$ saturation with reference to the atmosphere, Gran alkalinity has units of $\mu \mathrm{Eq}^{-1}$ and the $10^{6-\mathrm{pH}}$ term is an approximation of the hydrogen ion concentration in the same units. From this, BG1 and BG2 are respectively 18 and 8 times oversaturated with respect to atmospheric carbon dioxide. This means that on degassing the $\mathrm{pH}$ of these waters will increase to approximately 7.7 and 8.2 assuming surface waters are about 2 times over-saturated with respect to equilibrium with water in contact with the atmosphere. 
Table 3. Arithmetic mean, minimum and maximum in solute concentrations in groundwater in forest catchments at Beddgelert forest.

\begin{tabular}{|c|c|c|}
\hline & $B G 1$ & $B G 2$ \\
\hline \multirow[t]{2}{*}{$\mathrm{pH}$} & 6.73 & 7.49 \\
\hline & $5.86-7.23$ & $6.73-7.85$ \\
\hline \multirow[t]{2}{*}{ Alk $\left(\mu \mathrm{Eq} \mathrm{l}^{1^{-1}}\right)$} & 712 & 2291 \\
\hline & 286-1004 & 1984-2579 \\
\hline \multirow{2}{*}{$\mathrm{EpCO}_{2}$} & 18 & 12 \\
\hline & $8-117$ & $5-68$ \\
\hline \multirow[t]{2}{*}{$\mathrm{Na}\left(\mathrm{mg} \mathrm{l}^{-1}\right)$} & 4.4 & 23.3 \\
\hline & $3.7-5.3$ & $14.3-25.4$ \\
\hline \multirow[t]{2}{*}{$\mathrm{K}\left(\mathrm{mg} \mathrm{l}^{-1}\right)$} & 0.41 & 4.12 \\
\hline & $0.24-0.59$ & $2.78-4.53$ \\
\hline \multirow[t]{2}{*}{$\mathrm{Ca}\left(\mathrm{mg} \mathrm{l}^{-1}\right)$} & 15.7 & 30.6 \\
\hline & $7.9-22.0$ & $20.4-33.3$ \\
\hline \multirow[t]{2}{*}{$\operatorname{Mg}\left(\mathrm{mg} \mathrm{l}^{-1}\right)$} & 2.56 & 2.17 \\
\hline & $1.06-3.74$ & $1.64-2.52$ \\
\hline \multirow[t]{2}{*}{$\operatorname{Mn}\left(\mathrm{mg} \mathrm{l}^{-1}\right)$} & 0.42 & 0.17 \\
\hline & $0.01-1.68$ & $0.01-1.53$ \\
\hline \multirow[t]{2}{*}{$\mathrm{Al}\left(\mathrm{mg} \mathrm{l}^{-1}\right)$} & 0.01 & 0.02 \\
\hline & $<0.01-0.06$ & $0.01-0.10$ \\
\hline \multirow{2}{*}{$\mathrm{NH}_{4}-\mathrm{N}\left(\mathrm{mg} \mathrm{l}^{-1}\right)$} & 0.03 & 0.02 \\
\hline & $<0.01-0.41$ & $<0.01-0.16$ \\
\hline \multirow{2}{*}{$\mathrm{NO}_{3}-\mathrm{N}\left(\mathrm{mg} \mathrm{l}^{-1}\right)$} & 0.07 & 0.10 \\
\hline & $0.01-1.25$ & $0.01-0.88$ \\
\hline \multirow[t]{2}{*}{$\mathrm{SO}_{4}-\mathrm{S}\left(\mathrm{mg} \mathrm{l}^{-1}\right)$} & 3.46 & 3.31 \\
\hline & $2.38-4.18$ & $2.98-3.67$ \\
\hline \multirow[t]{2}{*}{$\mathrm{Cl}\left(\mathrm{mg} \mathrm{l}^{-1}\right)$} & 9.59 & 11.15 \\
\hline & $7.92-11.35$ & $9.93-12.52$ \\
\hline \multirow[t]{2}{*}{$\mathrm{Si}\left(\mathrm{mg} \mathrm{l}^{-1}\right)$} & 3.34 & 3.05 \\
\hline & $2.01-4.22$ & $1.73-3.72$ \\
\hline \multirow[t]{2}{*}{$\mathrm{DOC}\left(\mathrm{mg} \mathrm{l}^{-1}\right)$} & 1.4 & 2.78 \\
\hline & $0.1-13.5$ & $0.01-23.8$ \\
\hline \multirow[t]{2}{*}{ Cond $\left(\mu \mathrm{S} \mathrm{cm}^{-1}\right)$} & 122 & 266 \\
\hline & $78-154$ & $163-291$ \\
\hline \multirow[t]{2}{*}{ Water level (m) } & 0.97 & 1.27 \\
\hline & $0.02-1.65$ & $1.04-1.42$ \\
\hline
\end{tabular}

With the exception of sodium in BG1, the borehole waters are enriched in base cations, silicon, chloride and sulphate compared to the streams but depleted in aluminium. These waters are unlike any of the soil waters sampled at the site

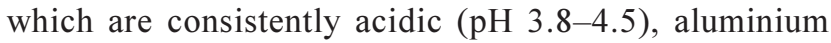
bearing (0.4-1.5 $\left.\mathrm{mg} \mathrm{l}^{-1}\right)$ and depleted in calcium (0.7-1.2 $\mathrm{mg} \mathrm{l}^{-1}$ ) throughout the profile (Stevens et al., 1989).

Although the boreholes are located only 150 metres apart, there are notable differences in their hydrological and hydrochemical characteristics. The average depth of water in the boreholes was approximately one metre, but water level fluctuations in BG1 were more dynamic than in BG2.
Concentrations of calcium, potassium, sodium and chloride are much greater in BG2 which is less acid than BG1 with an average Gran alkalinity in excess of $2000 \mu \mathrm{Eq} \mathrm{1}^{-1}$. This suggests that the two boreholes are intercepting separate groundwater reservoirs exposed to different weathering regimes; this is consistent with the high degree of spatial heterogeneity observed in groundwaters at Plynlimon (Hill and Neal, 1997; Neal et al., 1997).

\section{Discussion}

The monitoring at Beddgelert covers a period during which UK annual $\mathrm{SO}_{2}$ emissions declined by more than two thirds from $3720 \mathrm{kT} \mathrm{SO}_{2}$ in 1985 to $1156 \mathrm{kT} \mathrm{SO}_{2}$ in 2000 (NAEI, 2003). Correspondingly, annual wet deposition of nonseasalt sulphur at Beddgelert has approximately halved, with an annual rate of change very similar to that observed at UKADMN sites in northern England, central Wales and central southern England (NEGTAP, 2001). The results at Beddgelert are consistent with long-term records at Plynlimon in mid-Wales where a much smaller relative decrease in non-seasalt sulphur concentration in bulk precipitation was observed over 17 years from 1983 (Neal et al., 2001). Both studies provide examples of the spatially variable relationship between pollutant emission and deposition in the UK referred to as 'non-linearity' (NEGTAP, 2001 ) in which the reduction in wet sulphur deposition is smallest at remote westerly sites but largest near the main emission sources. Sulphur emissions from shipping in the Atlantic, background contributions from North American sources and increases over time in the rates of dry deposition of $\mathrm{SO}_{2}$, due to changes in the relative amounts of $\mathrm{SO}_{2}$ and ammonia in the air, are thought to be responsible for the observed non-linearity (NEGTAP, 2001).

Over the monitoring period, UK annual $\mathrm{NO}_{\mathrm{x}}$ emissions have declined from $2540 \mathrm{kT}$ in 1985 to $1512 \mathrm{kT}$ in 2000 , representing a $40 \%$ reduction (NAEI, 2003). However, there has been no discernible change in annual wet deposition of nitrate-N at Beddgelert; this is consistent with observations at Plynlimon and other western UK ADMN sites (NEGTAP, 2001; Neal et al., 2001) and more widely across many sites in Europe (Wright et al., 2001). Ammonia emissions are very uncertain, but published data indicate a $13 \%$ decline from $341 \mathrm{kT}$ in 1990 to $297 \mathrm{kT}$ in 2000 (NAEI, 2001). However, between 1992 and 1997, annual emissions stabilised at about $324 \mathrm{kT}$. The lack of a trend in ammonium concentrations and wet deposition is therefore unsurprising and consistent with data at Plynlimon and across the UK ADMN (NEGTAP, 2001; Neal et al., 2001).

The decline in non-seasalt sulphur deposition at Beddgelert is reflected in the declining concentrations of 
non-seasalt sulphate in both forest and moorland streams. Annual mean non-seasalt sulphur concentrations in streams D3 and D4, in which limited felling occurred prior to 1999 , follow very similar, parallel trends. At Plynlimon, it is more difficult to discern a clear trend from amongst the interannual fluctuations in concentration (Neal et al., 2001). The different responses at the two sites may be related to scaling, in that the Beddgelert catchments are smaller by a factor of 50 or more compared to those at Plynlimon. Clearfelling of nearly $70 \%$ of D2 appears to have caused a more rapid decline in sulphate concentrations, as removal of the majority of the forest canopy will have increased the water flux and decreased capture of cloud droplets and aerosols.

In conjunction with declining non-seasalt sulphur concentrations, stream acidity, aluminium and calcium concentrations have also decreased in the forest control stream (D3) in a manner consistent with observations at forested and non-forest acid sensitive surface water monitoring sites throughout the UK (Evans and Monteith, 2001; Harriman et al., 2001), Europe (Evans et al., 2001b; Skelkvåle et al., 2003) and north America (Stoddard et al., 1999) As with sulphate, there is an indication that large scale clearfelling of D2 has led to more rapid decreases in both calcium and aluminium compared to the other forest streams (prior to 1999), whereas there is no clear difference in $\mathrm{pH}$ trends amongst the forest streams. Reporting on acidity trends in the UK AWMN, Evans and Monteith (2001) suggested that trends in acidity-related variables were generally weaker in forest than in moorland systems. This does not seem to be the case at Beddgelert where stronger trends in calcium and aluminium are apparent in the forest streams. However, Evans and Monteith (2001) note that with only a small number of forest sites in the UK AWMN and considerable inter-site heterogeneity, it is difficult to generalise the effects of forestry on recovery from acidification. In a study of Scottish forest catchments, felling appeared to accelerate recovery trends with respect to acidifying components although forest streams were still more acid and contained higher concentrations of labile aluminium compared to moorland catchments (Harriman et al., 2003). At Beddgelert, the clear geochemical differences between D6 and the forest streams and the effects of clear felling are confounding factors in a forest-moorland comparison of acidity trends.

Variations in nitrate and potassium in the forest streams are dominated by the effects of forest harvesting and climatic variability. Despite the large variations in nitrate- $\mathrm{N}$ in D2, no clear acidification effect associated with forest harvesting is discernible from either weekly time series $\mathrm{pH}$ data (Stevens et al., 2001) or the annual mean values. The data record for stream water aluminium concentrations, however, post-date the clearfelling nitrate pulse. This is unfortunate, since it is possible that aluminium leaching may have responded strongly to the nitrate pulse in these very acid streams as shown by earlier work across 67 first-order stream sites in Wales (Neal et al., 1998). At Plynlimon, surface water acidification clearly accompanied the pulse of nitrate released at felling in the 13.7 ha, first order south2Hore catchment (Neal et al., 2003). As the nitrate pulse declined, acidification was reversed such that after five years, the stream had a higher $\mathrm{pH}$ and lower aluminium concentrations than before felling. Complete felling of small, first order streams represents the end-member case study where the most extreme responses are likely to be seen. Even at this scale, a spectrum of responses reflect the highly heterogeneous nature of upland systems with respect to soil types, chemical reactivity and hydrological pathways (Neal et al., 1998, 2004a, b). With an increase in scale to second and third order catchments, the net acidification effect of clearfelling may be hard to discern against other variations in water quality. This occurs when harvesting is phased across the catchment so that the effects of the standing forest, felling disturbance and post-felling recovery are integrated at the outflow (Neal and Reynolds, 1998; Neal et al., 2004). In such cases, factors such as climatic variability and longterm changes in pollutant deposition can dominate variations in water quality (Neal et al., 2004a, b and c)

In common with many upland catchments across the UK (Evans and Monteith, 2001), DOC concentrations have increased in both the moorland and forest streams over the last 20 years. This may be associated with increasing mobilisation of organic acids in response to a decrease in mineral acid inputs (Krug and Frink, 1983; Tipping and Hurley, 1988). However, it has been suggested that climatic controls are more important (Freeman et al., 2001), given that increases in DOC are observed at sites which have received relatively little acid deposition (Worral et al., in press). Even so, the strength of the trend can be quite variable, even within adjacent catchments subject to similar environmental conditions (Neal et al., 2001). The combination of increased $\mathrm{pH}$ and DOC in the streams at Beddgelert may have changed the speciation of aluminium which cannot be identified from the measurements of total monomeric aluminium. A decrease in the proportion of labile aluminium was reported at 10 out of 22 UK AWMN sites (Monteith and Evans, 2001). This reflects increased complexation by dissolved organic matter (Brown and Driscoll, 1993). This aluminium binding may well have resulted in a reduction in harm to aquatic biota as assessed using data from earlier toxicological studies (Baker and Schofield, 1982).

The occurrence of base-rich alkaline groundwater has 
been confirmed at Beddgelert in common with upland acidsensitive sites elsewhere in Wales (Neal et al., 1997; 2003) and in Scotland (Soulsby et al., 1998). The presence of groundwater helps to account for fluctuations in the calcium content of stream water in response to flow and the relatively large mass flux of calcium at the catchment outflows which could not be explained by sources within the soil profile at Beddgelert (Stevens et al., 1989). The contrasting hydrochemistry and hydrology of the two boreholes further demonstrates the complexity and heterogeneity of groundwater systems in upland catchments (Neal et al., 1997).

\section{Conclusions}

In response to declining industrial sulphur emissions, rainfall acidity and wet deposition of non-seasalt sulphur have decreased steadily since the early 1980s at Beddgelert Forest but the concentration or wet deposition of inorganic nitrogen is unchanged. There is a weak downward trend in non-seasalt calcium deposition, which may offset benefits following the decrease in sulphur deposition. Sulphate is still the dominant acid anion in precipitation, but its importance relative to nitrate has declined.

The long-term stream chemistry data from Beddgelert Forest provide evidence of recovery from acidification in response to decreasing wet sulphur deposition for a very acid-sensitive part of western Britain. The recovery trends in acidity related variables are evident in catchments under moorland, mature spruce forest and clear-felled / re-stocked forest. Forest nutrient cycling and harvesting have a major influence on stream water nitrate concentrations. A relatively short-lived nitrate leaching pulse follows harvesting. Subsequently, stream nitrate concentrations in the harvested catchment have approached values typical of the adjacent moorland stream, presumably due to forest re-growth.

Two boreholes drilled adjacent to the forest catchments have revealed shallow groundwater which is alkaline and base-rich in contrast to soil waters in the catchment which are acidic, base-poor and aluminium-rich. The groundwater provides a source of calcium which accounts for relatively high stream water calcium concentrations observed at baseflow and the relatively large mass flux of calcium at the outflows to the catchments calculated in earlier studies (Stevens et al., 1989).

In terms of broader issues of forest management and surface water quality, the Beddgelert studies provide examples of an 'end member' water quality response to clear felling consistent with other work on small, first order catchments in the UK (Adamson and Hornung 1990; Reynolds et al., 1995; Neal et al., 1998, 2003). The clear signals generated by such studies are invaluable for developing process understanding but they cannot necessarily be extrapolated directly to larger scale catchments, where the signals from a mosaic of forest management and other land uses are integrated at the catchment outflow. In such cases, the effects of climatic variability and long term changes in pollutant deposition may dominate patterns of variation in water quality. In regard to the latter, the long-term data sets at Beddgelert and other similar sites are of immense value in providing ground truth for model predictions and quantitative evidence of the effectiveness of emission control protocols for sulphur and nitrogen pollutants.

\section{Acknowledgements}

Numerous people have been involved with the project at Beddgelert Forest since its inception. The authors are particularly grateful, however, to all the Forestry Commission staff who have contributed to the project and allowed access to the sites. The work has been funded at various times by the Natural Environment Research Council, the Environment Agency, the Welsh Assembly Government (formerly Welsh Office) and the Department of Environment, Food and Rural Affairs (formerly the Department of the Environment).

\section{References}

Adamson, J.K. and Hornung, M., 1990. The effect of clearfelling a Sitka spruce (Picea sitchensis) plantation on solute concentrations in drainage water. J. Hydrol., 116, 287-297.

Baker, J.P. and Schofield, C.L., 1982. Aluminum toxicity to fish in acidic waters. Water Air Soil Pollut., 18, 289-309.

Blackie, J.R., Ford, E.D., Horne, J.E.M., Kinsman, D.J.J., Last, F.T. and Moorhouse, P., 1980. Environmental Effects of Deforestation: Occasional Publication No. 10, Freshwater Biological Association, Ambleside, UK. 173 pp.

Bormann, F.H. and Likens, G.E., 1979. Pattern and Process in a Forested Ecosystem. Springer, New York, USA. 253 pp.

Brown, B.A. and Driscoll, C.T., 1993. pH-dependent binding of aluminum by a fulvic-acid. Environ. Sci. Technol., 27, 915922.

Brown, G.W. and Krygier, T., 1971. Clear-cut logging and sediment production in the Oregon coast range. Water Resour. Res., 7, 1189-1198.

Dougan, W.K. and Wilson, A.L., 1974. The absorptiometric determination of aluminium in water. A comparison of some chromogenic reagents and the development of an improved method. Analyst, 99, 413-430.

Emmett, B.A. and Quarmby, C., 1991. The effect of harvesting intensity on the fate of applied ${ }^{15} \mathrm{~N}$-ammonium to the organic horizons of coniferous forest in N. Wales. Biogeochemistry, 15, 47-63.

Emmett, B.A., Anderson, J.M. and Hornung, M., 1991a. The controls on dissolved nitrogen losses following two intensities of harvesting in a Sitka spruce forest (N. Wales). Forest Ecol. Manage., 41, 565-80. 
Emmett, B.A., Anderson, J.M. and Hornung, M., 1991b. Nitrogen sinks following two intensities of harvesting in a Sitka spruce forest $(\mathrm{N}$. Wales) and the effects on the establishment of the next crop. Forest Ecol. Manage., 41, 81-93.

Emmett, B.A., Stevens, P.A. and Reynolds, B., 1995. Factors influencing nitrogen saturation in Sitka spruce stands in Wales, UK. Water Air Soil Pollut., 85, 1629-1634.

Evans, C.D. and Monteith, D.T., 2001. Chemical trends at lakes and streams in the UK Acid Waters Monitoring Network, 19982000: Evidence for recent recovery at a national scale. Hydrol. Earth Syst. Sci., 5, 351-366.

Evans, C.D., Monteith, D.T. and Harriman, R., 2001a. Long-term variability in the deposition of marine ions at west coast sites in the UK Acid Waters Monitoring Network: Impacts on surface water chemistry and significance for trend determination. Sci. Totat Environ., 265, 115-129.

Evans, C.D., Cullen, J.M., Alewell, C., Kopácek, J., Marchetto, A., Moldan, F., Pretchel, A., Rogora, M., Veselý, J. and Wright, R., 2001b. Recovery from acidification in European surface waters. Hydrol. Earth Syst. Sci., 5, 283-297.

Fahey, T.J., Hill, M.O., Stevens, P.A., Hornung, M. and Rowland, A.P., 1991a. Nutrient accumulation in vegetation following conventional and whole-tree harvest of Sitka spruce plantations in North Wales. Forestry, 64, 271-288.

Fahey, T.J., Stevens, P.A., Hornung, M., and Rowland, A.P., $1991 \mathrm{~b}$. Decomposition and nutrient release from logging residue following conventional harvest of Sitka spruce in North Wales. Forestry, 64, 289-301.

Feller, M.C., 1977. Nutrient movement through western hemlock - western red cedar ecosystems in southwest British Columbia. Ecology, 58, 1269-1283.

Freeman, C., Evans, C.D., Monteith, D.T., Reynolds, B. and Fenner, N., 2001. Export of organic carbon from peats. Nature, 412, 785 .

Harriman, R. and Morrison, B.R.S., 1982. Ecology of streams draining forested and non-forested catchments in an area of central Scotland subject to acid precipitation. Hydrobiol., 88, 251-263.

Harriman, R., Watt, A.W., Christie, A.E.G., Collen, P., Moore, D.W., McCartney, A.G., Taylor, E.M. and Watson, J., 2001. Interpretation of trends in acidic deposition and surface water chemistry in Scotland during the past three decades. Hydrol. Earth Syst. Sci., 5, 407-420.

Harriman, R., Watt, A.W., Christie, A.E.G., Moore, D.W., McCartney, A.G. and Taylor, E.M., 2003. Quantifying the effects of forestry practices on the recovery of upland streams and lochs from acidification. Sci. Total Environ., 310, 101-111.

Hill, T. and Neal, C., 1997. Spatial and temporal variation in $\mathrm{pH}$, alkalinity and conductivity in surface runoff and groundwater for the Upper Severn catchment. Hydrol. Earth Syst. Sci., 1, $697-715$.

Hornung, M., Bull, K.R., Cresser, M., Ullyet, J., Hall, J.R., Langan, S., Loveland, P.J. and Wilson, M.J., 1995. The sensitivity of surface waters of Great Britain to acidification predicted from catchment characteristics. Environ. Pollut., 87, 207-214.

Hughes, S., Norris, D.A., Stevens, P.A., Reynolds, B., Williams, T.G. and Woods, C., 1994. Effects of forest age on surface drainage water and soil solution aluminum chemistry in stagnopodzols in Wales. Water Air Soil Pollut., 77, 115-139.

Likens, G.E., Bormann, F.H., Pierce, R.S., Eaton, J.S. and Johnson, N.M., 1977. Biogeochemistry of a Forested Ecosystem, Springer, New York, USA. 146 pp.

Krug, E.C. and Frink, C.R., 1983. Acid rain on acid soil: a new perspective. Science, 221, 520-525.
McArdle, N., Liss, P. and Dennis, P., 1998. An isotopic study of atmospheric sulphur at three sites in Wales and Mace Head, Eire. J. Geophys. Res.-Atmos., 103, 31079-31094.

Monteith, D.T., Evans, C.D. and Reynolds, B., 2000. Are temporal variations in the nitrate content of UK upland freshwaters linked to the North Atlantic Oscillation? Hydrol. Process., 14, 17451749.

NAEI, 2003. UK National Atmospheric Emissions Inventory website www.naei.org.uk

Neal, C. and Kirchner,J.W., 2000. Sodium and chloride levels in rainfall, rust, streamwater and groundwater at the Plynlimon catchments, mid-Wales: inferences on hydrological and chemical controls. Hydrol. Earth Syst. Sci., 4, 295-310.

Neal, C. and Reynolds, B., 1998. The Impact of Conifer Harvesting and Replanting on Upland Water Quality. R\&D Technical Report P211, Environment Agency, Bristol, UK. 137 pp.

Neal, C., House, W.A. and Down, K., 1998. An assessment of excess carbon dioxide partial pressures in natural waters based on $\mathrm{pH}$ and alkalinity measurements. Sci. Total Environ., 210/ 211, 173-186.

Neal, C., Reynolds, B., Neal, M., Pugh, B., Hill, L. and Wickham, H., 2001. Long-term changes in the water quality of rainfall, cloud water and stream water for moorland, forested and clearfelled catchments at Plynlimon, mid-Wales. Hydrol. Earth Syst. Sci. 5, 459-476.

Neal, C., Reynolds, B., Neal, M., Wickham, H., Hill, L. and Pugh, B. 2003. The impact of conifer harvesting on stream water quality: A case study in mid-Wales. Water Air Soil Pollut. Focus, 3, 119-138.

Neal, C., Reynolds, B., Neal, M. and Williams, B., 2004a. The hydrochemistry of plantation spruce forest catchments with brown earth soils, Vyrnwy in mid-Wales. Hydrol. Earth Syst. Sci., 8, ***_****.

Neal, C., Reynolds, B., Neal, M., Wickham, H., Hill, L and Pugh, B., 2004b. The impact of conifer harvesting on stream water quality: the Afon Hafren, mid-Wales. Hydrol. Earth Syst. Sci., $8, * * * * * *$.

Neal, C., Neal, M., Reynolds, B., Maberly, S.C., May. L., Ferrier, R.C., Smith J. and Parker, J.E., 2004c. Silicon concentrations in UK surface waters. J. Hydrol., in press.

Neal, C., Robson, A.J., Shand, P., Edmunds, W.M., Dixon, A.J., Buckley, D.K., Hill, S., Harrow, M., Neal, M., Wilkinson, J. and Reynolds, B., 1997. The occurrence of groundwater in the Lower Palaeozoic rocks of Central Wales. Hydrol. Earth Syst. Sci., 1, 3-18.

Neal, C., Reynolds, B., Wilkinson, J., Hill, T., Neal, M., Hill, S. and Harrow, M., 1998. The impacts of conifer harvesting on runoff water quality: a regional survey for Wales. Hydrol. Earth Syst. Sci., 2, 323-344.

NEGTAP, 2001. Transboundary Air Pollution: Acidification, Eutrophication and Ground-level Ozone in the UK. National Expert Group on Transboundary Air Pollution, Centre for Ecology and Hydrology, Edinburgh, UK. 314 pp.

Reynolds, B., Neal, C., Hornung, M. and Stevens, P.A., 1986. Baseflow buffering of streamwater acidity in five mid-Wales catchments. J. Hydrol., 87, 167-185.

Reynolds, B., Stevens, P.A., Hughes, S., Parkinson, J.A. and Weatherley, N.S., 1995. Stream chemistry impacts of conifer harvesting in Welsh catchments. Water Air Soil Pollut., 79, 147170.

Reynolds, B., Lowe, J.A.H., Smith, R.I., Norris, D.A., Fowler, D., Bell, S.A., Stevens, P.A. and Ormerod, S.J., 1999. Acid deposition in Wales: the results of the 1995 Welsh Acid Waters Survey. Environ. Pollut., 105, 251-266. 
Seip, H.M., Muller, L. and Naas, A., 1984. Aluminium speciation: comparison of two spectrophotometric analytical methods and observed concentrations in some acidic aquatic systems in southern Norway. Water Air Soil Pollut., 23, 81-95.

Skjelkvåle, B.L., Evans, C., Larssen, T., Hindar, A. and Raddum, G., 2003. Recovery from acidification in European surface waters: A view to the future. Ambio, 32, 170-175.

Soulsby, C., Chen, M., Ferrier, R.C., Helliwell, R.C., Jenkins, A. and Harriman, R., 1998. Hydrogeochemistry of shallow groundwater in an upland Scottish catchment. Hydrol. Process., 12, 1111-1118.

Stevens, P.A. and Hornung, M., 1988. Nitrate leaching from a felled Sitka spruce plantation in Beddgelert Forest, North Wales. Soil Use Manage., 4, 3-9.

Stevens, P.A. and Hornung, M., 1990. Effect of harvest intensity and ground flora establishment on inorganic-N leaching from a Sitka spruce plantation in north Wales, UK. Biogeochemistry, 10, 53-65.

Stevens, P.A., Hornung, M. and Hughes, S., 1989. Solute concentrations, fluxes and major nutrient cycles in mature Sitka spruce plantation in Beddgelert Forest, North Wales. Forest Ecol. Manage., 27, 1-20.

Stevens, P.A., Adamson, J.K., Reynolds, B. and Hornung, M., 1990. Dissolved inorganic nitrogen concentrations and fluxes in three British Sitka spruce plantations. Plant Soil, 128, 103108.

Stevens, P.A., Williams, T.G. and Norris, D.A., 1993. Dissolved inorganic nitrogen budget for a forested catchment at Beddgelert, North Wales. Environ. Pollut., 80, 1-8.

Stevens, P.A., Norris, D.A., Sparks, T.H. and Hodgson, A.L., 1995. The impacts of atmospheric $\mathrm{N}$ inputs on throughfall, soil and stream water interactions for different aged forest and moorland catchments in Wales. Wat. Air Soil Pollut., 73, 297-317.
Stevens, P.A., Reynolds, B. and Neal, C., 2001. Trends in stream chemistry in upland catchments in Wales and effects of forest management. In: Detecting Environmental Change: Science and Society, $17^{\text {th }}-20^{\text {th }}$ July 2001, Abstracts, 161-162, London, UK.

Stoddard, J.L., 1994. Long-term changes in watershed retention of nitrogen - Its causes and aquatic consequences. Environmental Chemistry of Lakes and Reservoirs. Adv. Chem. Series, 237, 223-284.

Stoddard, J.L., Jeffries, D.S., Lükewille, A., Clair, T.A., Dillon, P.J., Driscoll, C.T., Forsius, M., Johannessen, M., Kahl, J.S., Kellogg, J.H., Kemp, A., Mannio, J., Monteith, D., Murdoch, P.S., Patrick, S., Rebsdorf, A., Skjelkvåle, B.L., Stainton, M.P., Traaen, T., van Dam, H., Webster, K.E., Wieting, J. and Wilander, A., 1999. Regional trends in aquatic recovery from acidification in North America and Europe. Nature, 401, 575578.

Stoner, J., Gee, A. and Wade, K., 1984. The effects of acidification on the ecology of streams in the Upper Tywi catchment in West Wales. Environ. Pollut. Series A, 35, 125-157.

Tipping, E. and Hurley, M.A., 1988. A model of solid-solution interactions in acid organic soils based on complexation properties of humic substances. J. Soil Sci., 39, 505-519.

Worrall, F., Harriman, R., Evans, C.D., Watts, C., Adamson, J., Neal, C., Burt, T., Grieve, I., Monteith, D., Naden, P.S. and Reynolds, B. Trends in dissolved organic carbon in UK rivers and lakes. Biogeochemistry, in press.

Wright, R.F., Alewell, C., Cullen, J.M., Evans, C.D., Marchetto, A., Moldan, F., Pretchel, A. and Rogora, M., 2001. Trends in nitrogen deposition and leaching in acid sensitive streams in Europe. Hydrol. Earth Syst. Sci., 5, 299-310. 